\title{
EATING HABITS AND STANDARD BODY PARAMETERS AMONG STUDENTS AT UNIVERSITY OF BANJA LUKA
}

\author{
Nela Raseta ${ }^{1}$, Slobodan Simovic ${ }^{2}$, Sonja Djuric ${ }^{1}$, Nenad Suzic ${ }^{3}$, Alma Prtina ${ }^{1}$, Nina Zeljkovic ${ }^{1}$ \\ ${ }^{1}$ Facuty of Medicine, University of Banja Luka, Bosnia and Herzegovina \\ ${ }^{2}$ Facuty of Physical Education and Sport, University of Banja Luka, Bosnia and Herzegovina \\ ${ }^{3}$ Faculty of Philosophy, University of Banja Luka, Bosnia and Herzegovina
}

\section{NAVIIE U ISHRANI I OSNOVNI TELESNI PARAMETRI KOD STUDENATA UNIVERZITETA U BANJA LUCI \\ Nela Rašeta ${ }^{1}$, Slobodan Simović ${ }^{2}$, Sonja Đurić ${ }^{1}$, Nenad Suzić ${ }^{3}$, Alma Prtina ${ }^{1}$, Nina Zeljković ${ }^{1}$ \\ ${ }^{1}$ Medicinski fakultet, Univerzitet u Banja Luci, Bosna i Hercegovina \\ ${ }^{2}$ Fakultet fizičkog vaspitanja i sporta, Univerzitet u Banja Luci, Bosna i Hercegovina \\ ${ }^{3}$ Fakultet za Filozofiju, Univerzitet u Banja Luci, Bosna i Hercegovina}

\begin{abstract}
Poor dietary habits have become one of the most important concerns among public health policy makers in recent years, due to the impact they have on both economic and health systems of a country. The transitional period toward young adulthood, marked with high school graduation and the beginning of college years, has been identified as critical in terms of its influence on young people's bad eating habits. The aim of this study was to assess whether the results obtained through Food Frequency Questionnaire significantly correlate with standard body parameters. Participants included 210 students from the University of Banja Luka, with the mean age of $21.94 \pm 2.73$ years. Factorization of Food Frequency Questionnaire Instrument extracted seven factors which were subjected to multiple regression analysis as independent variables, and correlated to dependent variables - anthropological measurements. This study shows that the factors labeled as consumption of bread, consumption of healthy food, and intake of carbohydrates, are significantly related to Body Fat Percentage, whereas factors labeled as intake offood of animal origin, and intake of fruits and vegetables, are statistically significant in terms of their relation to Waist-to-Hip Ratio. Only one factor, labeled as intake of unhealthy food, is significantly related to Body Mass Index; this is to suggest that Body Mass Index has again showed many limitations with regard to its research relevance. This research has also found that students of the University of Banja Luka typically consume white bread, known to have a direct link with overweight and obesity.
\end{abstract}

Keywords: Body Mass Index, Eating Habits, Food Frequency Questionnaires, Body Fat Percentage, Waist-to-Hip Ratio.

\section{SAŽETAK}

Loše navike u ishrani su postale jedna od najznačajnijih briga u politici javnog zdravlja poslednjih godina, jer one imaju uticaj kako na ekonomski tako i na zdravstveni sistem zemlje. Najkritičniji period u pogledu uticaja na stvaranje loših navika u ishrani je period odrastanja, odnosno period kraja srednje škole i početak fakulteta. Cilj ovog istraživanja bio je da se proceni da li rezultati dobijeni korišćenjem upitnika Food Frequency značajno koreliraju sa osnovnim telesnim parametrima. U istraživanju je učestvovalo 210 studenata sa Univerziteta u Banja Luci, prosečne starosti $21,94 \pm 2,73$ godina. Korišćeni upitnik je imao sedam faktora koji su podvrgnuti višestrukoj regresionoj analizi kao nezavisne varijable, a potom korelirani sa antropometrijskim merenjima koji predstavljaju zavisne varijable. Ova studija je pokazala da faktori označeni kao konzumiranje hleba, konzumiranje zdrave hrane i unos ugljenih hidrata su značajno povezani sa procentom masti u telu, dok su faktori označeni kao unos hrane animalnog porekla, unos voća i povrća značajno povezani sa odnosom obima struk/kuk. Samo jedan faktor, označen kao unos nezdrave hrane, je značajno povezan sa indeksom telesne mase, što još jednom ukazuje na činjenicu da indeks telesne mase ima dosta ograničenja u pogledu njegove relevantnosti za istraživanje. Takođe je ovim istraživanjem utvrđeno da studenti Univerziteta u Banja Luci tipično koriste beli hleb iako je poznatno da on dovodi do gojaznosti i nastanka prekomerne telesne mase.

Ključne reči: Indeks telesne mase, navike u ishrani, upitnik Food Frequency, procenat telesnih masti, odnos obima struk/kuk

\section{ABBREVIATIONS}

BMI - Body Mass Index FE - Faculty of Economics FFQ - Food Frequency Questionnaire FM - Faculty of Medicine
FPES - Faculty of Physical Education and Sport

BF\% - Body Fat Percentage

WHO - World Health Organization

WHR - Waist-to-Hip Ratio 


\section{INTRODUCTION}

Overweight and obesity prevalence across the globe (1) has witnessed a rising trend in the recent years, so that is almost possible to define it as a global pandemic (2), whereas its link to various diseases (3) puts it in the focus of public health debates (4). Overweight and obesity epidemic is equally found in developed and developing countries (5), and it is rapidly growing in the Third World Countries (6). It is recorded in all age groups including children, adolescents (4), and university students $(7,8)$.

Late adolescence and early adulthood period has been reported as indicative in relation to weight changes and adoption of poor dietary and exercise patterns (9); numerous studies from US have confirmed that freshman years among university students are critical in weight gain and behavioral patterns that may contribute to overweight and obesity (10-12). Weight gain in freshman college students and perceived health among European undergraduate has proven to follow the same pattern, but with a more pronounced perception of overweight and obesity among female students (8), even within other age groups $(13,14)$ (gender-sensitive dimorphism). However, a study carried out at the University of Banja Luka reported high prevalence of overweight and obesity $24.80 \%$, but with different results in comparison to other European countries, where male students were recorded to be more overweight/obese (17). Analyses of overweight and obesity prevalence conducted in the region of Southeastern Europe have come up with similar results (18-20).

World Health Organization defines overweight and obesity as abnormal or excessive fat accumulation that may impair health (21). This is not to suggest that there is a single individual according to whose body measures we can compare overweigh/obesity values, but the point is that the fundamental cause of obesity and overweight is an energy imbalance between calories consumed and calories expended (22). Dysfunction of feedback mechanism of satiety, hyperinsulinemia, insulin resistance and genetic predisposition, are seen as one the main causes of overweight and obesity (23). Some authors even define this term as obesogenic environment - an environment that promotes weight gain and offers a wide array of foods loaded with fat and sugar - nutrition known to have a jeopardizing effect on human metabolism (24). On the other hand, there are authors who link overweight and obesity with socioeconomic status of an individual, sedentary (urban) lifestyle, size of family, physical inactivity, educational status, cultural factors and bad eating habits (25).

Freshman adaptation to university life is highly demanding for young adults $(26,27)$, so if they fail to adequately adapt to this new environment, the poor dietary patterns and weight gain are likely to ensue (27). The reason probably lies in the fact that students experience certain number of transitional challenges when they transfer from secondary school to college environment, all of which may perpetuate in poor dietary and exercise patterns (28). Physical activity and proper eating habits are seen as key factors in the prevention of overweight-related diseases (29), whereas sedentary lifestyle and excessive calorie intake are labeled as two factors which contribute most to overweight and obesity. Changes in physical activity (30) during early college years (young adulthood) may contribute to overweight and obesity, as this is when adolescents change their behavioral and dietary patters (31). Moreover, academic burden students experience on the daily basis is discouraging with regard to adoption of healthy eating and exercise habits (32). Changes in weight, composition and shape of body are reported to be significant and incremental, and they may result in rather unfavorable lifelong health issues $(33,34)$.

Prevalence of underweight, alongside with overweight and obesity, has been reported in university students from the region of Murcia (35). Olearo et al. (36) claim that $12.5 \%$ of university students are underweight, while a study carried out by Pelzner et al. (7), as well as other similar researches (37), found underweight prevalence more common among female students. Raseta et al. (17), and other authors from our region (18-20), came up with similar findings. This is to say that the issue of underweight should receive an adequate attention as well (38).

The aim of this study was to investigate whether the results obtained through self-reported Food Frequency Questionnaire [FFQ] correlate with values measured by Body Mass Index [BMI], Body Fat Percentage [BF\%] and Waist-to-Hip Ratio [WHR] in students from the University of Banja Luka.

\section{MATERIALS AND METHODS}

This study was conducted as the cross-sectional one, with 210 participants from the University of Banja Luka - the mean age $21.94 \pm 2.73$ years. Out of the total number of participating students, 30 per year of study (firstand third-year students) were from the Faculty of Physical Education and Sport [FPES], and the Faculty of Economics [FE] - total of 120 students; and 90 were students from the Faculty of Medicine [FM] - 30 students per year of study (first, third, fifth). Male to female ratio was imbalanced (107 male or 50.95\%, and 103 female or $49.05 \%$ ) due to the general gender structure at the Faculty of Physical Education and Sport, and Faculty of Economics. Students were recruited on a voluntary basis, and an informed consent from the students was obtained prior to their participation. This study was carried out in accordance with the highest ethical principles set out in the Declaration of Helsinki (DoH), and it was compliant with the similar legislation concerning human experimentation in Bosnia and Herzegovina.

Anthropometric measurements were performed in accordance with the recommendations from the International Biological Program (IBP) and World Health Orga- 
nization (WHO). The measurements were performed at the Institute of Sport of the Faculty of Physical Education and Sport, during the months of May and June 2015. The students were measured according to the following parameters: Body Mass (measured in kilograms using medical weighing scales having precision of $0.1 \mathrm{~kg}$ ), Body Height (the height was taken barefoot in centimeters by using the Martin anthropometer, and it was recorded with the precision of $0.1 \mathrm{~cm}$ ), Waist Circumference (measured at the midpoint between the lowest point of the rib cage and the highest point of femoral crest of the pelvic bone), Hip Circumference (measured at the widest point while being at level with the trochanter), Biceps Skinfold (measured on the anterior side of the middle of forearm just above $m$. biceps), Triceps Skinfold (measured on the dorsal side of the middle of forearm just above m. biceps), Subscapular Skinfold (measured below the lower edge of the scapula), and Suprailiac Skinfold (measured $1 \mathrm{~cm}$ above and $2 \mathrm{~cm}$ medially from anterior superior iliac spine (ASIS) - spina iliaca anterior superior). Circumferences were recorded by using measuring tape having precision of $0.1 \mathrm{~cm}$, while skinfold measurements were obtained using a John Bull Calipers with $0.2 \mathrm{~mm}$ precision and standard pressure of $0.01 \mathrm{~Pa}$ on $1 \mathrm{~mm}^{2}$ of skin.

According to WHO's overweight and obesity factsheet (39), BMI values were determined as follows: $\leq 18.5$ underweight, between 18.5 and 24.9 normal (healthy) weight, 25.0 - 29.9 overweight, and $\geq 30$ obese. WHR values were classified according to WHO's recommendations (40), and with respect to gender dimorphism - females: $<0.75$ excellent, 0.75-0.79 good, 0.80-0.86 average and $>0.86$ at risk, and males: $<0.85$ excellent, 0.85-0.89 good, 0.90-0.95 average, and $>0.95$ at risk. The calculation of Body Fat Percentage was based on the formula developed by Durin and Womersley (41), with predicted values for 17-29 years old people expressed as logs of the total four skinfold types. The classification of the obtained values was performed in accordance with Bray (42), again with the respect of the gender dimorphism - females: $20-30 \%$ physiological (normal) values, 30-33\% overweight, $>33$ obesity; males: $12-20 \%$ physiological (normal) values, $20-25 \%$ overweight, $>25 \%$ obesity.

As an index of weight-for-height, BMI has been regarded as simple but at the same time the method with serious limitations (43) when it comes to body composition analysis within an entire population. $\mathrm{BMI}$ and $\mathrm{BF} \%$ tend to be misinterpreted, particularly when observed across different age groups. BMI is comprised of both fat and muscle mass, so it sometimes can be misleading in terms of evaluating somebody's overweight and obesity status, especially in people with normal or relatively low values of BF\% (44) - professional athletes for example (18). Although BMI values in middle-aged people (45) can be relevant, in younger population, however, BMI is seen as the least reliable predictor of overweight and obesity. Though it has been used much less than BMI, WHR provides more accurate results with respect to body composition (45).
In order to track down the history of dietary habits in university students, we designed FFQ instrument (46), with an intention to account for how often and how much certain amount of food was consumed during the reference period (47). Calibration was performed by factor analysis (Brattlett Test of Sphericity was significant at $p<0.01$, and Kaiser-Meyer-Olkin Measure of Sampling Adequacy showed that indicators of sampling adequacy were higher than $0.40-K M O=0.68$ ), and the number of extracted factors was seven, out of which six had Cronbach's Alpha quotient at above 0.50: (a) intake of food of animal origin ( $\alpha=0.72)$; (b) consumption of white bread $(\alpha=0.92)$; (c) consumption of healthy food ( $\alpha=0.63)$; (d) intake of unhealthy food ( $\alpha=0.63)$; (e) intake of carbohydrates $(\alpha=0.43)$; (f) consumption of milk and dairy products $(\alpha=0.71)$; (g) consumption of fruits and vegetables $(\alpha=0.77)$. The respondents were asked to provide answers on a Likert-type scale ranging from 1 to 9: $1=$ never, $2=$ once a month, $3=$ twice a month; $4=$ once a week; 5 = twice a week; $6=3-4$ times a week; $7=5-6$ times a week; 8 = once a day; and $9=$ twice a day. One of the items relating to the intake of food of animal origin read: How often do you eat meat? The following items exemplify the nature of the other remaining factors: consumption of healthy food - How often do you eat fish?; intake of unhealthy food - How often do you eat sweets?; consumption of milk and dairy products - How often do you eat dairy products?; etc.

The data were coded and entered into a database. We used simple descriptive statistics to provide basic information about the overall characteristics of the sample - Onetailed Bivariate Correlation, factor analysis with Varimax rotation (characteristic values over 1.00), Chronbach's Alpha quotient, and multiple regression analysis. Statistical analyses were carried out with IBM SPSS Statistics 21.0.

\section{RESULTS}

The overall view on the obtained results points to the following means of the observed parameters: male students - WHR $(M=0.84, S D=0.52), \mathrm{BF} \%(M=15.47, S D$ $=3.50)$, and BMI $(M=24.36, S D=2.59)$; female students - WHR $(M=0.72, S D=0.04), \mathrm{BF} \%(M=25.14, S D=3.59)$ and BMI $(M=21.54, S D=2.46)$. Mean values by fields of study (faculty attended) and gender are shown in Figure 1, with WHR results presented in Graph $1, \mathrm{BF} \%$ results in Graph 2, and BMI in Graph 3. The first indicators in all the three graphs give mean values for the observed parameter - for the students of the Faculty of Physical Education and Sport, the Faculty of Economics and the Faculty of Medicine, respectively.

With respect to FFQ Instrument, Figure 2 gives clear evidence that the curve of mean values across items is almost identical. Tested students reported the highest value answers (i.e. 5-6 times a week) for item How often do you eat bread? $(M=7.27, S D=0.16)$. Consumption of food 

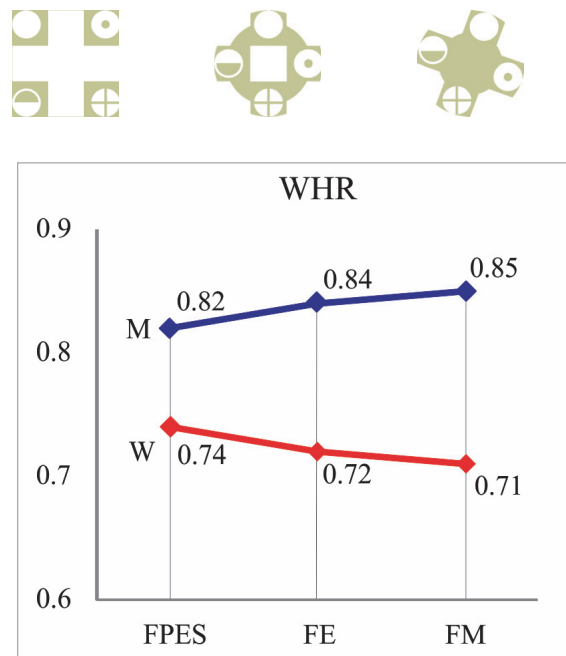
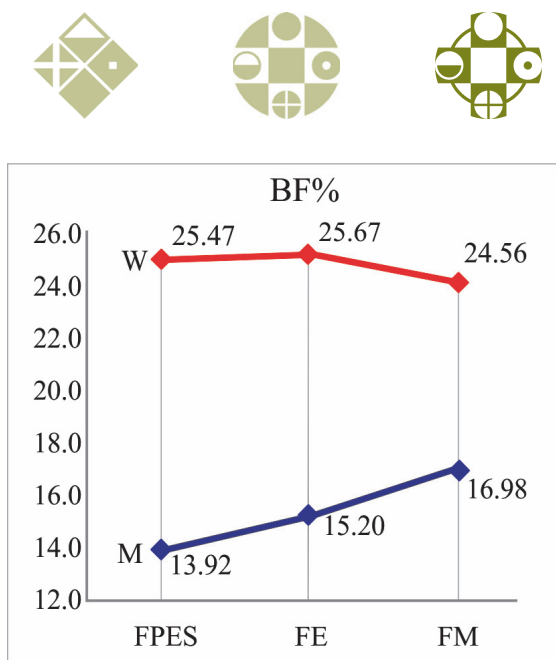
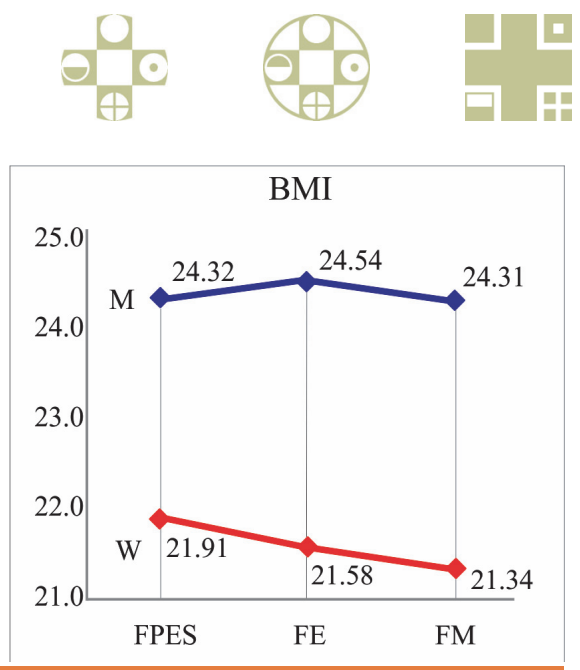

Figure 1

Legend: WHR - Waist-to-Hip Ratio; BF\% - Body Fat Percentage; BMI - Body Mass Index; FPES - Faculty of Physical Education and Sport; FE - Faculty of Economics; FM - Faculty of Medicine; M - Men; W - Women.

3-4 times a week was recorded for the items How often do you eat white bread? $(M=6.91, S D=0.18)$, How often do you eat fruits? $(M=6.91, S D=0.11)$, How often do you eat meat? $(M=6.67, S D=0.11)$ and How often do you eat vegetables? $(M=6.57, S D=0.12)$. The lowest value (i.e. twice a month) was recorded for the item How often do you eat whole wheat pasta? $(M=2.62, S D=0.12)$, whereas on the following items: How often do you eat fish? $(M=3.30, S D$ $=0.11)$, How often do you drink skimmed milk? $(M=3.62$, $S D=0.17)$, and Do you eat margarine or butter? $(M=3.79$, $S D=0.15)$ students responded with once a week answers.
Triangular correlation matrix between the extracted factors following the factorization of FFQ instrument and the assessment results for variables WHR, BF\% and BMI shows that $\mathrm{BF} \%$ is partially correlated at $p<0.05$ level with the following four extracted factors: positively with consumption of bread and intake of unhealthy food, and negatively with consumption of healthy food and intake of carbohydrate; WHR correlates with three factors: positively with intake of food of animal origin and intake of carbohydrates, and negatively with consumption of fruits and vegetable; BMI has only one negative correlation - namely with intake of unhealthy food.

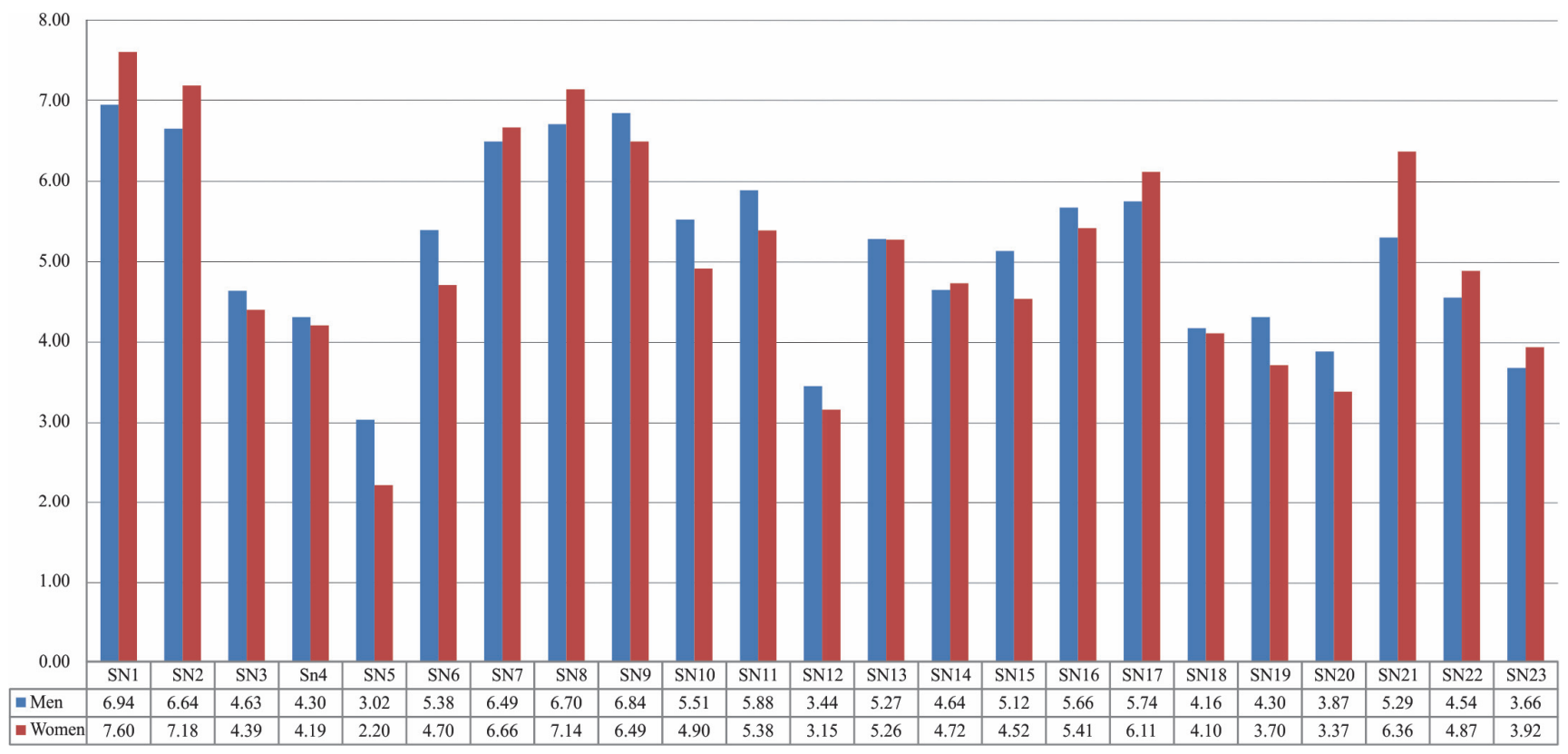

Figure 2

Legend: SN1 - How often do you eat bread?; SN2 - How often do you eat white bread?; SN3 - How often do you eat cereals (cornflakes, etc.)?; SN4 How often do you eat white flour pasta (spaghetti, macaroni)?; SN5 - How often do you eat whole wheat pasta?; SN6 - How often do you eat potatoes?; SN7 - How often do you eat vegetables?; SN8 - How often do you eat fruits?; SN9 - How often do you eat meat?; SN10 - How often do you eat red meat?; SN11 - How often do you eat chicken and lean meat?; SN12 - How often do you eat fish?; SN13 - How often do you eat eggs?; SN14 - How often do you eat delicatessen food?; SN15 - How often do you eat legumes (beans, peas, pulses)?; SN16 - How often do you drink milk?; SN17 - How often do you eat dairy products?; SN18 - How often do you consume whole milk dairy products?; SN19 - How often do you consume partly skimmed milk?; SN20 - How often do you consume skimmed milk?; SN21 - How often do you eat sweets?; SN22 - How often do you eat snacks?; SN23 - Do you consume margarine or butter? 

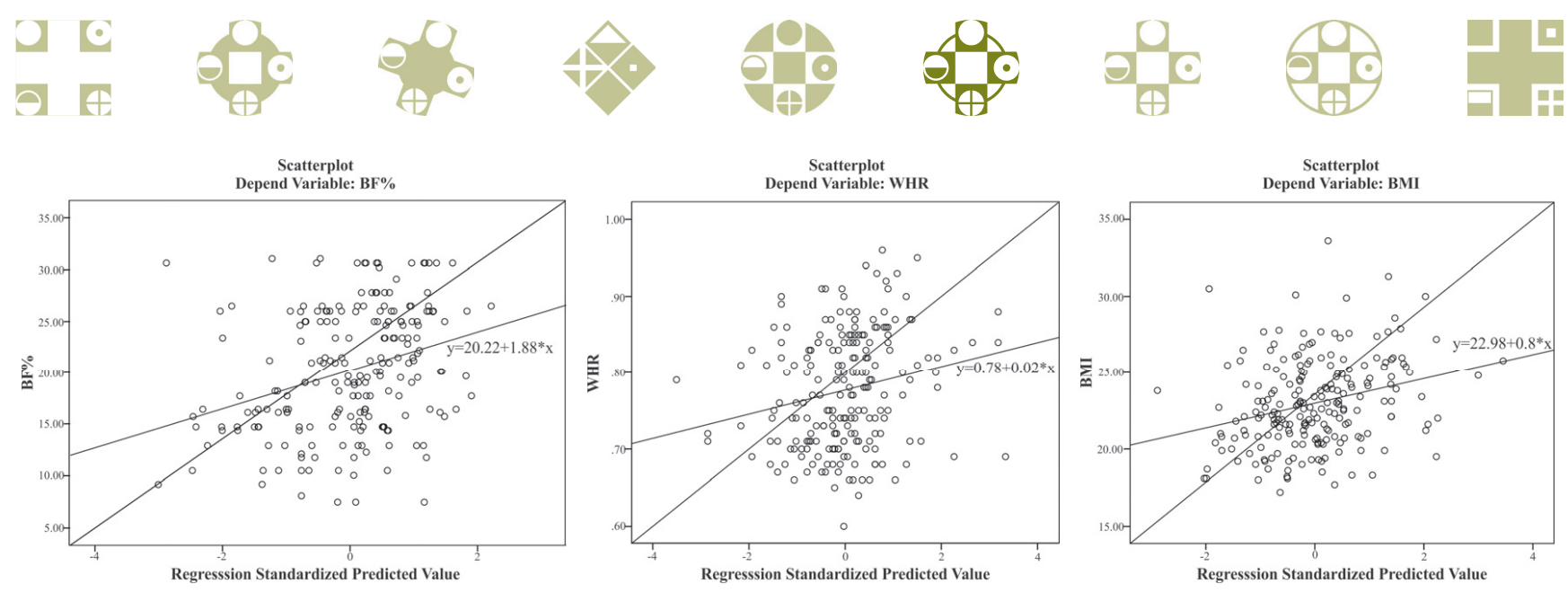

Figure 3

The dependent variable BF\% shows statistically significant correlation $\left(F_{(3,206)}=7.48 ; p=0.00\right)$ in the third iteration of Stepwise Regression Model, with following three factors extracted from the FFQ instrument: consumption of bread $(p=0.00)$, intake of carbohydrates $(p=0.01)$ and consumption of healthy food ( $p=0.05)$.

The dependent variable WHR shows statistically significant correlation, $\left(F_{(2,207)}=4.71 ; p=0.01\right)$ in second iteration, with two factors: consumption of fruit and vegetables $(p=0.01)$ and intake of food of animal origin $(p=0.03)$.

Regression analysis for $\mathrm{BMI}$ is not here provided due to the fact that triangular matrix of partial correlations shows that BMI only correlates with one out of seven factors, namely intake of unhealthy food, at $p<0.05$ level.

Diagrams of dispersion of residues indicate that there is a clear dependence between residues and predicted values for all three dependent variables, which is consistent with the linearity assumption (Figure 3).

\section{DISCUSSION}

Raseta et al. (17) showed that, according to WHR, $98.10 \%$ of male and $87.90 \%$ of female students fell within limits marked as excellent and good. Only $1.90 \%$ of male students had average (within borderlines) results, while female students fared a bit worse $(11.20 \%$ were average, and $1.00 \%$ were at risk of overweight). In terms of percentage distribution, $\mathrm{BF} \%$ variable had $74.80 \%$ of male and $72.00 \%$ of female students within physiological (normal) values, $15.50 \%$ male students and $11.20 \%$ female students fell within overweight category, whereas $9.70 \%$ males and $16.80 \%$ females were underweight. The observed group of undergraduate students recorded no cases of obesity. Percentage distribution of BMI variable classified $70.90 \%$ students within normal values, $22.40 \%$ overweight, $2.40 \%$ obesity, and $4.30 \%$ underweight. Raseta et al. (17) appear to have substantiated the widespread claims that student population is witnessing an increase in overweight and obesity prevalence regardless of the part of the world it occurs (7), with the region of the Southeastern Europe being no exception (48). If these results are set against similar studies from the European context (8), we cannot help but to conclude that they are inversely proportional to the results presented by our European fellow researchers. In a research that included participants from $16 \mathrm{Eu}-$ ropean countries, female students were reported to have larger proportion in overweight and obesity category as compared to male students. Some other studies from our region $(18-20,49,50)$, as well as from other Eastern European countries (51), have confirmed the same trend of overweigh and obesity among university students. Davar (5) concludes that almost all countries are facing obesity endemic, although great variations exist between and within countries. More interestingly, underweight prevalence is on the rise among students, especially among female students (38), which has been corroborated by the study carried out on the population of university students in Banja Luka (17). This phenomenon might be interpreted as female students' concern about their appearance, which is hugely influenced by women celebrities. Their primary motivation to stay slim could be driven by the desire to attract the attention of the opposite sex, peer support, and increase of self-confidence (52).

Bad eating habits, physical inactivity, and sedentary lifestyle can all predispose university students to face weight issues (13), i.e. reduced physical activity and high caloric diet are almost certain risk factors of overweight and obesity in student population (31). As noted before, the transition between adolescence and adulthood, a common age for university attendance, is accompanied by weight gain, so it is obvious that there is a need to initiate lifestyle changing strategies at this particular period of life if we want to prevent overweight and obesity, and contribute to improve one's exercise and diet habits in the long run (53).

Regression analysis of FFQ Instrument in third iteration extracted three factors that correlate with $\mathrm{BF} \%$ variable with statistical significance. The first factor was labeled consumption of bread and it included two items from FFQ Instrument: (a) How often do you eat bread? - students responded 5-6 times a week, and (b) How often do you eat white bread? - students responded 3-4 times a week. The second factor, labeled as intake of carbohydrate, 
included three items from FFQ Instrument: (a) How often do you eat white flour past (macaroni, spaghetti)? - the response was once a week; (b) How often do you eat potatoes? - twice week, and (c) How often do you eat legumes (beans, peas, pulses)?- once a week; the third factor was labeled as consumption of healthy food and it was consisted of five FFQ Instrument items: (a) How often do you eat cereals (cornflakes, etc.)? - twice a week; (b) How often do you eat whole wheat pasta? -once a month; (c) How often do you eat fish? - twice a month; (d) How often do you consume partly skimmed milk? - once a week, and (e) How often do you consume skimmed milk? - once a week. The obtained results clearly indicate that white bread consumption, which is associated with fast food, is strongly correlated with weight gain and occurrence of overweight and obesity. On the other hand, intake of healthy food recorded very poor results in terms of its frequency among students from the University of Banja Luka. There are numerous studies which provide plentiful evidence with regard to bad dietary habits in student population (54). Some researchers (48, 55) from our region even go further to conclude that 60$70 \%$ of students have bad eating habits. Such dietary pattern is closely linked with weight gain in this population. Food preference and widespread availability of fast food are also contributing to negative eating environment surrounding young students (56). Various reasons are seen to be underlying in this respect: lack of available information on healthy food choices (57), financial side of the food issue - unhealthy food is readily available for less money than healthy food (58), students' financial status (59), as well as exposure to high level of stress among university students, particularly before exams (60). Some US studies have also found that reduced intake of healthy food and bread is a trade-off for increased consumption of fat-loaded food and alcohol (61).

Two factors exhibited statistically significant correlation with variable WHR (in second iteration). The first factor was labeled as consumption of fruits and vegetables and it included two items from FFQ Instrument: How often do you eat vegetables? and How often do you eat fruits? - students came up with answers 3-4 times a week. The second factor was labeled as intake of food of animal origin and it included the following four items: (a) How often do you eat meat? students responded 3-4 times a week; for questions (b) How often do you eat red meat?; (c) How often do you eat chicken and lean meat; and (d) How often do you eat eggs? students gave the same answers - twice a week. Romaguera et al. (62) found that diet with plenty of fruits and dairy products, and little white bread, processed meat, margarine and soft drinks (non-alcoholic beverages), can prevent gain of visceral fat. Students who show tendency towards eating less of fruits and vegetables than recommended on the daily basis, are inclined to drinking alcohol, overeating fast food, and succumbing to excessive calorie intake (14), all of which predispose them to overweight and obesity $(13,54)$. The present study shows that, in comparison to other types of food, the tested students exhibited preferences towards fruits and vegetables - the similar findings have been presented by Yahia et al. (63). Contrary to the popular belief though, some authors found no correlation between consumption of fruits and vegetables accompanied by physical activity, and prevention of overweight and obesity (64).

BMI was correlated with only one factor, labeled as intake of unhealthy food, which included the following four items: (a) How often do you eat sweets? - twice a week was students' response, (b) Do you consume margarine or butter? - twice a month, for (c) How often do you eat delicatessen food?, and (d) How often do you eat snacks?, students responded once a week. Excessive intake of sweets among college students has been in the focus of different studies (53); an increased consumption of snacks before exams in student population was also recorded (48). Increased BMI values have been reported as being in close relation to excessive sweets intake in younger population (65). However, BMI has repeatedly been found insufficient of providing apt classification with regard to weight (nutritional) status of university students. Similar findings appear to have been substantiated by the present study as well - which provides yet another insight into the limitations of BMI's reliability $(5,17,45)$.

There are of course certain limitations to this study. First of all, classification of students into the two following categories - (a) those who continue to live at their parents' home during their studies, and (b) those who move away from their parents - would be beneficial as there are numerous researches supporting claims that students who change their permanent residence tend to be more susceptible to dietary changes (66). Furthermore, the number of participating students and faculties is surely one of the most serious limitation. What is more, students often showed little or no motivation to participate in studies of this kind.

It is opined that further research into the issue of eating habits and their impact of body and weight status among student population, should be carried out in the form of longitudinal study with two dependent variables, namely BF\% and WHR. That would also call for adjustments in FFQ Instrument, in order to eliminate drawbacks noticed during the present study. Finally, the number of participants in any future research should be increased.

\section{CONCLUSION}

The vast amount of research findings provided by this paper conclusively correlates Body Fat Percentage, Waist-to-Hip Ratio and dietary habits of the participating students. Bread consumption has been found to stand in the highest correlation to Body Fat Percentage. This implicitly assumes that the students from the University of Banja Luka tend to consume too much fast food and thus account for an increased number of student population in overweight category. 


\section{REFERENCES}

1. Di Cesare M., Bentham J., Stevens G.A., et al. (2016). Trends in adult body-mass index in 200 countries from 1975 to 2014 : A pooled analysis of 1698 population-based measurement studies with 19.2 million participants. Lancet, 387(10026), 1377-1396. DOI: 10.1016/S0140-6736(16)30054-X

2. Ng M., Fleming T., Robinson M., et al. (2014). Global, regional, and national prevalence of overweight and obesity in children and adults during 1980-2013: A systematic analysis for the Global Burden of Disease Study 2013. Lancet, 384(9945), 766-781. DOI: 10.1016/ S01406736(14)604608.

3. Roger V.L., Go A.S, Lloyd-Jones D.M., et al. (2012). Executive summary: Heart disease and stroke statistics - 2012 update a report from the American Heart Association. Circulation, 125(1), 188-197. DOI: 10.1161/ CIR.0b013e3182456d46

4. Ogden C.L., Carroll M.D., Kit B.K., et al. (2014). Prevalence of obesity and trends in body mass index among US children and adolescents, 1999-2010. J Am Med Assoc, 307(5), 483-490. DOI: 10.1001/jama.2012.40

5. Davar V. (2015). Body composition analysis of university students by anthropometry and bioelectrical impedance analysis. International Journal of Medical, Health, Biomedical, Bioengineering and Pharmaceutical Engineering, 9(6), 492-496. DOI: scholar.waset. org/1999.9/10001563

6. Moore S., Hall J.N., Harper S., et al. (2010). Global and national socioeconomic disparities in obesity, overweight, and underweight status. Journal of Obesity, ID 514674, 1-11. DOI:10.1155/2010/514674

7. Peltzer K., Pengpid S., Samuels T.A., et al. (2014). Prevalence of overweight/obesity and its associated factors among university students from 22 countries. Int. J. Environ. Res. Public Health, 11(7), 7425-7441. DOI:10.3390/ijerph110707425

8. Wardle J., Haase A.M. \& Steptoe A. (2006). Body image and weight control in young adults: International comparisons in university students from 22 countries. International Journal of Obesity, 2006, 30(4), 644-651. DOI: $10.1038 /$ sj.ijo.0803050

9. Vadeboncoeur C., Townsend N. \& Foster C. (2015). A metaanalysis of weight gain in first year university students: is freshman 15 a myth? BMC Obes., 2(22), 1-9. DOI: 10.1186/s40608-015-0051-7

10. Blondin S.A., Mueller M.P., Bakun P.J., et al. (2016) Cross-sectional associations between empiricallyderived dietary patterns and indicators of disease risk among university students. Nutriens, 8(1), E3. DOI: 10.3390/nu8010003

11. Girz L., Polivy J., Provencher V., et al. (2013). The four undergraduate years. Changes in weight, eating attitudes, and depression. Appetite, 69, 145-150. DOI: 10.1016/j.appet.2013.06.002

12. Kapinos K.A., Yakusheva O. \& Eisenberg D. (2014). Obesogenic environmental influences on young adults:
Evidence from college dormitory assignments. Econ Hum Biol., 12, 98-109. DOI: 10.1016/j.ehb.2013.05.003

13. Deliens T., Clarys P., De Bourdeaudhuij I., et al. (2014). Weight, sociodemographic, and health behaviour related correlates of academic performance in first year university students. Nutr. J., 12(162), 1-9. DOI: 10.1186/1475-2891-12-162

14. de Vos P., Hanck C., Neisingh M., et al. (2015). Weight gain in freshman college students and perceived health. Prev Med Rep, 2, 229-234. DOI: 10.1016/j.pmedr.2015.03.008

15. Hedley A.A., Ogden C.L., Johnson C.L., et al. (2004). Prevalence of overweight and obesity among US children, adolescents, and Adults, 1999-2002. JAMA, 291(23): 2847-2850. DOI: 10.1001/jama.291.23.2847

16. Ogden C.L., Flegal K.M., Carroll M.D., et al. (2002). Prevalence and trends in overweight among US children and adolescents, 1999-2000. JAMA, 288(14), 1728-1732. DOI: 10.1001/jama.288.14.1728

17. Rašeta N., Đurić S., Zeljković N., et al. (2017). Interrelationships between Body Mass Index, Percent Body Fat, and Waist-to-Hip Ratio among different groups of student at University of Banja Luka. Facta Universitatis, Series: Physical Education and Sport, 14(3), 331-345. DOI: 10.22190/FUPES1603331R.

18. Crnobrnja V., Srdić B., Stokić E., et al. (2012). Analysis of obesity prevalence in students from Novi Sad. Med Pregl, 65(3-4), 133-137. DOI: 10.2298/MPNS1204133C

19. Simić S., Vasić G. \& Jakonić D. (2010). Body height, body weight and nutritional status in students of the University of Novi Sad. Med Danas, 9(4-6), 141-146.

20. Stojanović D., Višnjić A., Mitrović V., et al. (2009). Risk factors for the occurrence of cardovascular system diseases in students. Vojnosanit Pregl., 66(6), 453-458. DOI: 10.2298 /VSP0906453S

21. World Health Organization. (2016). Obesity and Overweight [homepage on the Internet]. Retrived from: http://www.who.int/mediacentre/factsheets/fs311/en/ index .html.

22. Kumah D.B., Akuffo K.O., Abaka-Cann J.E., et al. (2015). Prevalence of overweight and obesity among students in the Kumasi Metropolis. Journal of Nutrition and Metabolism, ID 613207, 1-4. DOI: http:// dx.doi.org/10.1155/2015/613207

23. Codogno P. \& Meijer A.J. (2010). Autophagy: A potential link between obesity and insulin resistance. Cell Metabolism, 11(6), 449-451. DOI: 10.1016/j. cmet.2010.05.006.

24. David H. (2010). An integrative view of obesity. The American Journal of Clinical Nutrition, 91(1), 280S283S. DOI: 10.3945/ajcn.2009.28473B

25. Al-Nuaim A.A., Al-Nakeeb Y., Lyons M., et al. (2012). The prevalence of physical activity and sedentary behaviors relative to obesity among adolescents from Alahsa, Saudi Arabia: Rural versus urban variations. Journal of Nutrition and Metabolism, ID 417589, 1-9. DOI: $10.1155 / 2012 / 417589$ 
26. Dyson R. \& Renk K. (2006). Freshmen adaptation to university life: depressive symptoms, stress, and coping. J Clin Psychol, 62(10), 1231-1244. DOI: 10.1002/ jclp.20295

27. Von Ah D., Ebert S., Ngamvitroj A., et al. (2004). Predictors of health behaviors in college students. J Adv Nurs, 48(5), 463-474. DOI: 10.1111/j.13652648.2004.03229.x

28. Crombie A.P., Liu P.Y., Ormsbee M.J., et al. (2012). Weight and body-composition change during the college freshman year in male general-population students and army Reserve Officer Training Corps (ROTC) cadets. Int. J. Sport Nutr. Exercise Metab., 22(6), 412-421. DOI: $10.1111 /$ j.1753-4887.2008.00143.x

29. Moreno-Gómez C., Romaguera-Bosch D., Tauler-Riera P., et al. (2011). Clustering of lifestyle factors in Spanish university students: The relationship between smoking, alcohol consumption, physical activity and diet quality. Public Health Nutrition, 15(11), 2131-2139. DOI:10.1017/S1368980012000080

30. Racette S.B., Deusinger S.S., Strube M.J., et al. (2005). Weight changes, exercise, and dietary patterns during freshman and sophomore years of college. J. Am. Coll. Health, 53(6), 245-251. DOI:10.3200/JACH.53.6.245-251

31. LaCaille L.J., Dauner K.N., Krambee, R.J., et al. (2011). Psychosocial and environmental determinants of eating behaviors, physical activity, and weight change among college students: A qualitative analysis. Journal of American College Health, 59(6), 531-538. DOI: 10.1080/07448481.2010.523855

32. Romo Báez A.S., Tejada Tayaba L.M., Pastor Durango M.P., et al. (2015). Prevalence and factors associated with overweight and obesity among university students of the health field in San Luis Potosí México. Health, 7, 328-335. DOI: 10.4236/health.2015.73037

33. Gropper S.S., Simmons K.P., Connell L.J., et al. (2012). Changes in body weight, composition, and shape: A 4-year study of college students. Appl. Physiol. Nutr. Metab., 37(6), 1118-1123. DOI: 10.1139/h2012-139

34. Gropper S.S., Simmons K.P., Connell L.J., et al. (2012). Weight and body composition changes during the first three years of college. J. Obes., 634048, 1-6. DOI:10.1155/2012/634048

35. Cutillas A.B., Herrero E., de San Eustaquio A., et al. (2013). Prevalence of underweight, overweight and obesity, energy intake and dietary caloric profile in university students from the region of Murcia. Nutr Hosp, 28(3), 683-689. DOI: 10.3305/nh.2013.28.3.6443

36. Olearo B., Soriano Del Castillo J.M., Boselli P.M., et al. (2014). Assessment of body composition, through anthropometric and non-anthropometric methods, of university students from valencia. Nutr Hosp, 30(4), 911-918. DOI: 10.3305/nh.2014.30.4.7676

37. Gopalakrishnan S., Ganeshkumar P., Prakash M.V., et al. (2012). Prevalence of overweight/obesity among the medical students, Malaysia. Med J Malaysia, 67(4), $442-444$.
38. Ren X., Chen Y., He L., et al. (2015). Prevalence of underweight, overweight and obesity in university students from the region of Anhui (China). Nutr Hosp., 31(3), 1089-1093. DOI:10.3305/nh.2015.31.3.8395

39. World Health Organization Regional Office for Europe. (2016). Body mass index - BMI. [homepage on the Internet]. Retrieved from: http://www.euro.who.int/en/ health-topics/disease-prevention/nutrition/a-healthylifestyle/body-mass-index-bmi\#

40. World Health Organization. (2008). Waist circumference and Waist-hip ratio, Report of a WHO Expert Consultation. Geneva, Switzerland: World Health Organization.

41. Durnin J.V.G.A. \& Womersley J. (1974). Body fat assessed from the total body density and its estimation from skinfold thickness: measurements on 481 men and women aged from 16 to 72 years. British Journal of Nutrition, 32(1), 77-97. DOI: 10.1079/BJN19740060

42. Bray G.A. (2004). Classification and Evaluation of the Overweight Patient. In: G.S. Bray \& C. Bouchard (Eds.), Handbook of obesity: Clinical applications, 2nd ed (pp. 1-32). New York, NY: Marcel Dekker, Inc.

43. Deurenberg-Yap M., Schmidt G., van Staveren W.A., et al. (2000). The paradox of low body mass index and high body fat percent among Chinese, Malays and Indians in Singapore. Int J Obes Relat Metab Disord, 24(8), 1011-1017.

44. Freedman D.S., Ogden C.L. \& Kit B.K. (2015). Interrelationships between BMI, skinfold thicknesses, percent body fat, and cardiovascular disease risk factors among U.S. children and adolescents. BMC Pediatrics, 15(188), 1-9. DOI: 10.1186/s12887-015-0493-6

45. Dagan S.S., Segev S., Novikov I., et al. (2013). Waist circumference vs body mass index in association with cardiorespiratory fitness in healthy men and women: a cross sectional analysis of 403 subjects. Nutrition Journal, 12(12), 1-8. DOI: 10.1186/1475-2891-12-12

46. Prtina, A. (2010). The incidence of metabolic syndrome in medical workers the city of Banja Luka. Unpublished master's thesis, University of Banja Luka, Banja Luka, Bosnia and Herzegovina.

47. Thompson F.E. \& Subar A.F. (2013). Dietary assessment methodology. In A.M. Coulston, C.J. Boushey \& M.G. Ferruzzi (Eds.), Nutrition in the prevention and treatment of disease, 3rd ed (pp. 5-46). San Diego, CA: Academic Press.

48. Milošević Georgiev A. \& Krajnović D. (2016). Risk factors for the development of hypertension related to nutrition habits in students of the University of Belgrade. Timočki medicinski glasnik, 41(3), 203-207.

49. Gazibara T., Kisic Tepavčević D.B., Popović A., et al. (2013). Eating Habits and Body-weights of Students of the University of Belgrade, Serbia: A Cross-sectional Study. J Health Popul Nutr., 31(3), 330-333.

50. Štalić Z., Čolić Barić I. \& Keser I. (2007). Diet quality in Croatian university students: Energy, macronutrient and micronutrient intakes according to gender. International Journal of Food Sciences and Nutrition, 58(5), 398-410, DOI: 10.1080/09637480701252393 
51. Kolarzyk E., Pac A., Shpakou A., et al. (2012). Cent, Eur. J. Med., 7(5), 665-671, DOI: 10.2478/s11536-012-0028-6

52. Malinauskas B.M, Raedeke T.D., Aeby V.G., et al. (2006). Dieting practices, weight perceptions, and body composition: A comparison of normal weight, overweight, and obese college females. Nutrition Journal, 5(11), 1-8. DOI:10.1186/1475-2891-5-11

53. Huang T.T., Harris K.J., Lee R.E., et al. (2016). Assessing overweight, obesity, diet, and physical activity in college students. Journal of American College Health, 52(2), 83-86. DOI: 10.1080/07448480309595728

54. Deshpande S., Basil M.D. \& Basil D.B. (2009). Factors influencing healthy eating habits among college students: An application of the Health Belief Model. Health Marketing Quarterly, 26(2), 145-164. DOI: 10.1080/07359680802619834

55. Zeković M., Stojković T., Milošević Georgiev A., et al. (2015). Research on presence of chosen risk factors for hypertension in medical students. Praxis medica., 44(2), 13-19.

56. Ansari W.E., Suominen S. \& Samara A. (2015). Eating habits and dietary intake: Is adherence to dietary guidelines associated with importance of healthy eating among undergraduate university students in Finland? Cent Eur J Public Health, 23(4), 306-313. DOI: 10.21101/cejph.a4195

57. Gan W.Y., Mohd N.M., Zalilah M.S., et al. (2011). Differences in eating behaviors, dietary intake and body weight status between male and female Malaysian university students. Malays J Nutr., 17(2), 213-228.

58. Drewnowski A. \& Specter S.E. (2004). Poverty and obesity: the role of energy density and energy costs. Am J Clin Nutr., 79(1), 6-16.
59. Jessop D.C., Herberts C. \& Solomon L. (2005) The impact of financial circumstances on student health. Br J Health Psychol., 10(Pt 3), 421-439. DOI: 10.1348/135910705X25480

60. Fabián C., Pagán I., Ríos J.L., et al. (2013). Dietary patterns and their association with sociodemographic characteristics and perceived academic stress of college students in Puerto Rico. P R Health Sci J., 32(1), 36-43.

61. Butler S.M., Black D.R., Blue C.L., et al. (2004). Change in diet, physical activity, and body weight in female college freshman. Am J Health Behav, 28(1), 24-32. DOI: 10.5993/AJHB.28.1.3

62. Romaguera D., Ängquist L., Du H., et al. (2011). Food composition of the diet in relation to changes in Waist Circumference adjusted for Body Mass Index. PLoS One., 6(8), e23384. DOI: 10.1371/journal.pone.0023384

63. Yahia N., Achkar A., Abdallah A., et al. (2008). Eating habits and obesity among Lebanese university students. Nutrition Journal, 7(32), 1-6. DOI:10.1186/1475-2891-7-32

64. Nikolaou C.K., Hankey C.R. \& Lean M.E.J. (2015). Weight changes in young adults: A mixedmethods study. International Journal of Obesity, 39(3), 508-513. DOI:10.1038/ijo.2014.160

65. Payab M., Kelishadi R., Qorbani M., et al. (2015). Association of junk food consumption with high blood pressure and obesity in Iranian children and adolescent: CASPIAN - IV Study. Jornal de Pediatria, 91(2), 196-205. DOI: 10.1016/j.jped.2014.07.006

66. Lupi S., Bagordo F., Stefanati A., et al. (2015). Assessment of lifestyle and eating habits among undergraduate students in northern Italy. Ann Ist Super Sanità, 51(2), 154-161. DOI: 10.4415/ANN_15_02_14 